\title{
Futural Dispatches on Responsibility for the Earth, or, 'What on Earth Is Ethical Responsibility?'
}

\author{
Dave Boothroyd
}

\section{check for}

updates

Citation: Boothroyd, Dave. 2022. Futural Dispatches on Responsibility for the Earth, or, 'What on Earth Is Ethical Responsibility?'. Humanities 11: 18. https://doi.org/10.3390/ h11010018

Received: 8 November 2021

Accepted: 13 January 2022

Published: 17 January 2022

Publisher's Note: MDPI stays neutral with regard to jurisdictional claims in published maps and institutional affiliations.

Copyright: (c) 2022 by the author. Licensee MDPI, Basel, Switzerland. This article is an open access article distributed under the terms and conditions of the Creative Commons Attribution (CC BY) license (https:// creativecommons.org/licenses/by/ $4.0 /)$.
School of Social Policy, Sociology and Social Research, University of Kent, Kent CT2 7NZ, UK; ProfDBoothroyd@gmail.com

\begin{abstract}
This article explores the question of the limits of ethical responsibility in the context of the contemporary ecological crisis. Drawing centrally on a selection of writings by Jacques Derrida, Emmanuel Levinas and, in the second half of the article especially, Timothy Morton, it attempts to show how the conceptualization of the Earth/environment/biosphere (tropes for the 'ecological whole') as an object of ethical concern is problematic and exacerbated in the context of the posthumanist critique of anthropocentrism. If a generalized anthropization of the planet represents the 'ethical failure' of the Earth by 'the human' - the material mark of which is the geo-physical terraforming associated with anthropocene-who or what, might be anticipated to be able to bear, or to live-up to, the ethical responsibility for its continued survival? The article critically brings elements of the philosophy of these thinkers into conjunction to discuss how the future of life/death might be properly considered an ethical matter at all, or alternatively, as the 'end' of ethical responsibility. Whilst Morton appears to recognize the potential of deconstructive thinking and Levinasian ethics for ecological thought, it is argued here that his reading of these is at odds with the object-oriented ontological thinking he more stridently identifies with. This messy collision in Morton's ecological theory is used here as a springboard to explain how a strategic reprise of a certain humanism-or theoretical human exceptionalism—-might be key to appreciating how humans taking responsibility for the current ecological crisis is the condition of a futural ethical openness to the non-human.
\end{abstract}

Keywords: ecological crisis; apocalypticism; Derrida; Morton; Kant; ethics; lifedeath; survivance

The radical character of the ecological crisis is not to be underestimated. The crisis is radical not only because of its effective danger, i.e., it is not just that what is at stake is the very survival of humankind. What is at stake is our most unquestionable presuppositions, the very horizon of our meaning, our everyday understanding of "nature" as a regular, rhythmic process. (Žižek 1992, p. 24)

In his 1980 essay 'Of An Apocalyptic Tone Recently Adopted in Philosophy', Derrida cites John, Revelations 3, 1-3:

'Stay awake! Strengthen what remains, so near dying.

If you do not stay awake I shall come like a thief: you will not know at what hour I shall come upon you' (Derrida 1984, p. 25)

Immediately afterwards Derrida writes ponderously, perhaps ruefully repeating it to himself: "I shall come: the coming is always to come", and wonders "where does this coming come from?" This line of questioning, Derrida shows, necessarily concerns the "narrative voice" of the Apocalypse (itself) as an event, and as that which must logically precede any narratology as such. For this reason, and in view of this aporia, both the meaning of this revelation and on whose authority 'it comes' will remain, precisely, questionable. We know it came to John, the apostle who wrote it, supposedly from Jesus who spoke it, though only indirectly via a messenger, an angel. Its origin, the original emission, however, is necessarily obscured by the passing-on, not to mention any further obscuration arising from problems of translation incurred at any point in this chain, which includes my 
now passing-on this message in this context, namely a discussion of ethical responsibility in view of the planetary ecological crisis. (Needless to say, this is something that was not anticipated, by John, by Jesus, by some nameless angel, nor by the translators of the biblical text and of Derrida's French text nor, of course, by Derrida himself). To paraphrase Derrida's lengthy meditation on this aspect of transmission: the revelation or sending (envoi) of the apocalypse, that is, as a message or a dispatch (envoi), is indistinguishable from the apocalypse itself. There is no original sender, rather, the apocalypse is a dispatch or sending that "sends itself". It can always be said of the apocalypse, therefore, that it is here now and yet to come; it is both a message and an event, or the message as an event. Moreover, by extension of this reasoning, there is no inscription of the event, this or any other, that is not already apocalyptic through and through. It is always upon us-it is now 'up to us'.

Anyone familiar with Derrida's oeuvre will be familiar with the pattern, at least, of this sort of argumentation-which, whatever its thematic focus, is always also a querying and a response to 'the end', both in the sense of the purpose that it serves and, moreover, as a finality that can neither be made present nor fully known. It invokes an enigmatic, indefinitely postponed forever-ending. Emphatically, this is not to be construed as a mystical affair; it is, rather a mark of insistence on the futurity of that which is always yet to come. So, on this basis at least; on this basis above all, there is a sense in which deconstruction/the Derridean oeuvre in its entirety is concerned with 'endings'.

Derrida wrote voluminously, explicitly and directly about death, dying and of mortality, notably, for example, in texts such as: The Gift of Death (Derrida 1995); Aporias: Dying-Awaiting (One Another At) the 'Limits of Truth' (Derrida 1993); in his 'eulogies' in The Work of Mourning (Derrida 2001). Furthermore, he had already addressed these topics at length in his seminars of 1974/5, the 'life/death' series, published in English for the first time just last year (Derrida 2020) and in 'Living On: Border Lines' (Derrida 1979). Unsurprisingly, he continued to do so in his final 'deathbed interview' published as 'Learning to live finally: The last interview', the year after he died in 2004 (Derrida 2007). Bearing this in mind, I believe it is with some license that I begin this essay by way of reference to the 'Apocalyptic Tone' essay. To be honest though, strictly speaking, I have cited it out of context here, in so far as it does not address the theme of ecological disaster as such, and its account of 'the apocalyptic', as I have indicated, remains generic. Re-reading it today, I shall argue, it does nonetheless express something important in relation to the coming catastrophe and the alarm (the 'wake-up call', or the 'stay awake call') that critical ecological thought is variously sounding. I shall explain what that is in a moment.

In this essay, Derrida deconstructs a short polemical text by Kant from 1796 in which Kant is criticizing the 'superior tone' (erhobenen vornehmenen Ton), as he calls it, of those of his critics who suppose that speculative thinking and intuition alone is able to "reach beyond the limits of possible empirical knowledge by purely conceptual means and, as such, is devoid of (any) practical relevance". (Backman 2017, pp. 105-6; Kant 2002, p. 444). For Kant, these critics and all pre-critical thought are guilty of "eschatological mystagogy" (or in plain Anglo-Saxon English, quasi-mystical bullshit). "The mystagogues make a scene, that is what interests Kant" (Derrida 1984, p. 8). Derrida's reading of Kant's view of this aims to show that by insisting on an absolute distinction between pre-critical philosophy and his own, Kant unwittingly freed up "another wave of eschatological discourses" that thereafter came to dominate 19th and 20th century thought (Derrida 1984, p. 20). Not only that, but by declaring that there can be no such "immediate and absolute final revelation in philosophy; no apocalypse in the literal sense of the Greek apokalypsis" then this itself is in fact an apocalyptic gesture. "If the apocalypse reveals", says Derrida further on, "it is first of all the revelation of the apocalypse" (itself, qua apocalypse)—“"the self-presentation of the apocalyptic structure of language, of writing, of the experience of presence, in other words, of the text or of the mark in general". (Derrida 1984, pp. 27-28. Emphasis is my own).

So why is this text worth revisiting in the context of today's ecological crisis? For two reasons, I suggest: firstly as it reminds us to be vigilant with respect to end-of-times- 
thinking that falls, or is at risk of falling, into the error of "eschatological mystagogy"; and secondly, and more importantly for what I want to discuss here, it begs the question, perhaps opens, or keeps open, the question of responsibility for the future as a matter of ethical responsibility. How so? By forcing the issue of survival, which is, and in a way always has been, survival beyond the apocalypse, to be addressed explicitly as a matter of ethical concern for us, we the living, beyond our own finite lives/deaths, now, in the present. 'Yes, yes, yes', one might say, 'of course, we (the living) bear an ethical responsibility, alongside political, economic and technological responsibilities, surely that goes without saying'. However that is not what I wish to emphasize here. There is a problem. The problem is that we lack a sufficiently meaningful concept for the 'who or what' that is ethically responsible; and, it is neither clear for whom or for what this ethical subject is, putatively, responsible nor is it known from whom or what the apocalyptic message comes. (I assume, for sake of argument, the reader does not believe in the existence of a mystical, Platonic netherworld which is home to all the future unborn individuals or forms of life just waiting for their chance to arrive!) Nor are we able to decide to whom or to what 'the message' is addressed. Is it to 'all of us', we humans-as a species, or perhaps, to each one of us in our singular finitude - each of whom, like all life forms on Earth, are mortal and destined to die soon enough anyway? Is it possibly emanating from a super-entity such as 'Gaia', possessing a teleology of its own and being capable of such a cosmic 'note-to-self' - a missive, as it were, by virtue of our being privy to it, revealing to us the nature of our own culpability vis-à-vis the true nature of our part in the damage; in the ailing of the Earth biosphere?

Notwithstanding the difficulty and the perplexity surrounding the conceptualization of the 'ecological whole', or the 'environment' and the place of the human within it, the question of the limits of ethical responsibility and questions relating to what can be done and what has a chance of actually being done about the 'crisis' are connected: the conundrum of ethical responsibility is both philosophical and quotidian. Ethical failure as a failure of eco-ethical thinking is evident often in the paucity of the practical quotidian responses to the ecological crisis. Small-scale measures, for example, the domestic recycling of plastic waste through to large-scale policies directed at the de-carbonization of the global economy, are not themselves material manifestations of 'eco-ethical decisions' in the sense I want to discuss here. To suppose that they are, is to forget that the geophysical terraforming of the Earth and of its eco-systems that we call the anthropocene has already happened: the issue is, and in a rather obvious way, the survival and the sustainability of survival itself in the post-anthropocene. However, what is far from obvious and remains undecided is what this means or, more to the point, what this might turn out to be, could be, or ethically speaking, ought to be. May one not ask, meaningfully (perhaps even sincerely) and not immorally, 'what is so bad about a sixth extinction?' After all, it was the Yucatan meteorite extinction event 66 million years ago that gave our mammalian ancestors their chance at becoming the ethically troubled species we are today. I pose this question here heuristically, of course, yet also seriously as it represents a pithy provocation to thinking ethically about the presumed value of survival it appears to challenge. There is a serious point to be made relating to the presumed illegitimacy, or absurdity of such a perspective on the anthropogenic transformation of the earth biosphere, and the 'crisis' viewed in terms of 'extinction'. Extinction stands here as the figure of 'death' par excellence. This presumption, however, forecloses the chance the crisis presents to think 'survival' anew; it bears within it the denial of this chance (opportunity) to think beyond the notion of life (and above all human life) as being a value, even the source of all value, in itself (in other words as being a 'natural', or 'God-given' value.) Playfully, though not frivolously, in a text of 1979 Derrida dwells on the problematics of privileging the notion of life over that of death:

Who can really speak about living? Who is in a position to? Who is already on the other side, little enough alive, or alive enough, to dare to speak, not about one life, nor even about life, but about living... Is it really a question of living? In other words, who said that we had to live? But who's talking about living? Must we live, really? Can "living", 
"live", be taken as an imperative, an order of necessity? Where do you get this axiomatic, valuational certainty that we (or you) must live? That it's better to live than to die? That, since we've started, we have to keep on living? In other words, living-on ... (Derrida 1979, pp. 78-79)

As already noted, this deconstructive re-writing of the life/death distinction and thinking of their non-difference is a hallmark of the Derridean oeuvre tout court. The notion, and the question of survival outside of the presumption of its exclusive reference to 'life' as opposed to and distinct from 'death', is marked in the Derridean corpus by the term survivance. This is his name for the possible (though not guaranteed) continuance of the life-death cycle of mortality beyond the life and death of any particular living entity or life form, be it human and non-human. In other words, we cannot begin to think about the continuance of life as an ethico-ecological issue if we do not think it through the inseparability of life (and) death. ${ }^{1}$ The word survivance in Derrida's discourse expresses the notion of continuance of a certain vitality, or thriving of living-dying, which is neither exclusively human nor is its referent the multiplicity of human and non-human mortal life comprising the biosphere either. Survivance is an attempt to name what only appears, or 'comes' to the mortal (and perhaps only the human) in the form of an ethical demand. It is only in the post-anthropocene, and partly in response to a certain prevailing cultural 'apocalypticism', I suggest, that we can, perhaps, begin to think ethical responsibility through this conjuncture (the non-difference of life and death) and at this (temporal-historical) conjuncture we call the anthropocene. The ethical, and hence the ethico-political 'problem', if it can be properly called this, concerns how we should conceive of, let alone how we can live-up to, the notion of ethical responsibility for the survivance of this thing we call the Earth-environmentbiosphere. (We might just say 'Earth' for simplicity). The question alone, unanswered, belies precisely the hitherto ethical failure of the Earth that the anthropocene is the indelible mark of.

One may well ask: do we in fact need to conceptualize planetary ethical responsibility at all in order to move on, that is, to survive? Do we need even to conceptualize 'the Earth' as if it were a closed planetary system at all-indeed, are we inclined to do so simply as to us from space it looks like a like a bubble, or a spaceship, and due to this being our anthropological habit? After all, Earth has its own place and its own chances of survival (or not) in a dynamic solar system and a greater cosmos. The hubris of thinking of it as 'ours alone' and as if it were our property, is not lost on many of 'us' humans today, possibly on some non-humans too. So that is why I pose the question here, 'what on Earth is responsibility?' It is a question that, even when unanswered, punctures anthropocentrism like no other.

As you probably know, the rhetorical questioning tone of the use of this phrase in the English language-'What on Earth is X? - expresses surprise, bewilderment and incredulity at the seemingly improbable existence of the thing in question. The double entendre of the question here usefully points to the dissonance between the notion of ethicality as such in conjunction with an 'earthliness' we only know on the basis of the anthropization of the Earth. How could there be an ethical responsibility, on, for, or toward 'the Earth' /'environment' / 'biosphere', that rests on anything other than an anthropocentric ethic?

The issue I am raising concerns above all the limits of ethical responsibility-which may or may not be 'mine' - each of ours individually, or even 'ours' as a species, collectively, or perhaps 'ours' only in sense of an as-yet unknown form of 'we' that may only become known in the future, post-humanly. If ethical responsibility is 'real' rather than an illusory product of anthropization, then its 'origin' must come from beyond this anthropized-totality we currently inhabit. It must be futural in the sense already suggested by Derrida: ethical demand and survivance must, in a sense be coterminal, co-original. In other words, survivance in Derrida's discourse should perhaps be read as an attempt to think the preservation of living (life-death cycle) as an absolute ethical value. Clearly, as this stands, it remains a form of meta-ethical questioning of the limits of responsibility 
rather than a matter for normative ethical debate, although arguably there is little prospect for the latter without some regrounding of normativity in the former, and certainly not without de-anthropomorphizing our thinking of ethicality altogether. Derrida's thinking of the apocalyptic structure of all communication can be of assistance in such a quest, I suggest, not so much due to the ethical incoherence or perplexity it seeks to resolve from a philosophical perspective, but rather as ultimately it will have a bearing on the prospects for the survival (survivance) of whomever or whatever is to come in the future of this 'thing' we can only ever vaguely and uncertainly posit as the 'the Earth' / 'the environment' / 'the biosphere'. My entire argument here concerns, then, why the question of ethical responsibility for the Earth cannot be reduced to the problem of human knowledge of it.

What is ethically troubling and what is ethically troubled in this ailing of the Earth, which is at once, in part, an ailing in (or of) me? This 'thing' - let me just call it that as it slips my grasp-and this being-ethically-troubled are not the same, to be sure. However, it is also true that one can barely tell them apart or sustain their separateness. This (Earth-thing) is in a way 'me' (at least it includes me, ontologically speaking) although it is also the not-me; it is the Same and it is the Other-but then, not just any-other. For sure it will not be gone with my death. Only an anethical narcissist such as Macbeth (or a Donald Trump) might really think like that. Shakespeare's Macbeth says: "I 'gin to be aweary of the sun/And wish the estate o'the world were now undone" (5.5 49-50) "I have lived long enough". Would that he could will the world into nothingness with his death, Macbeth knows it will live on. ${ }^{2}$ For Emmanuel Levinas, Macbeth in death represents the antithesis of the ethical relation to the Other: Levinas says my death is secondary to the death of the Other; not as logically (that is chrono-logically) the death of the other precedes my own; and not as I am a good person, compassionate, caring, aiming to do the right thing, habitually altruistic - no, not at all that 'cuddly stuff,'. Levinas says my death is secondary as the relation to the Other in his or her (or its) dying and, as such, is radically outside of the temporality of the finitudinal, mortal, life-death cycle. (Levinas 2000, p. 43; Boothroyd 2013, pp. 202-3). Ethicality is thus a burden, an uninvited obligation and a never fully answerable, interminable demand. This is very closely related to what Derrida invites us to contemplate as survival beyond the apocalypse (survivance) in connection with the forever-coming, rather than the arrival, of 'the end'. (This is a theme that could be traced even more widely in his expanded discourse of the arrivant).

So, this Earth-environment thing: it certainly exceeds my human finitude. However, will it come like a thief in the night or more like Santa Claus? Is it threatening or is it promising something? A gift perhaps? Does it present itself (to us) as a gift, one that historically and up until the anthropocene we have mistakenly taken as being for-us? Furthermore, have we treated it as if it were an inexhaustible 'standing reserve' (Gestell) to use a Heideggerian term central to his critique of modernity - a technically-enframed, extractive resource in other words; a gift, we came to assume, that was the gift that would keep on giving - and which today, many live in hope, might continue to give. If we respond by ending the consumption of it; by giving up on consume(r)ism in the most general senseas the ultimate form of what Stiegler (2018) calls 'anthropization', and which is currently in its 'critical' end phase-is that what ethical responsibility ultimately demands today?

In the second half of this article I shall turn to the work of Timothy Morton, to some the doyen, to others the Malvolio, of contemporary critical ecology ${ }^{3}$, and someone who, rather provocatively, often casts his commitment to 'object-oriented ontology' as working within a post-deconstructive tradition. I am interested here specifically in his account of ethicality and how, or whether, he presents a notion of the ethico-ecological in a coherent and potentially more decisive way. (Spoiler alert: it will shortly become clear I do not think he actually does this, and in what follows immediately I am in effect using his work as a critical 'stepping stone' toward my own later claim, or suggestion, that posthumanist approaches to thinking ethico-ecologically always risk letting the singular nature 'human-species' responsibility for the ecological crisis off the hook.) 
One model of the ethical in Morton's thinking that springs to mind is the image he provides in Ecology Without Nature when reworking what Hegel says in the Phenomenology of Spirit (Ch. 6 On Spirit) about the ethical subject as a 'beautiful soul'. Exactly as does Hegel, Morton gives us both a positive and a negative image of the beautiful soul. The negative perhaps is the most important for him as he even says that: "Without doubt the discovery of the beautiful soul as the form of ecological consumerism is the most important concept of this book". (Morton 2007, p. 121, emphasis is my own). By way of an analogy drawn from Quantum Theory, Morton's image is of a soul that pops in and out of existence in the way subatomic particles can, and, alternatively it can be in the state of being nowhere in particular, or, everywhere-at-once. In this Quantum Theory analogy the beautiful soul is in 'superposition'; when and where it pops into existence corresponds to the Quantum Theory concept of the collapse of the wave function. When it is in the 'everywhere at once state', so to speak, he says "ethical space opens up and 'spreads out endlessly in all directions'-[and becomes] ethical ambience". It is the spreader and in itself the spreading out of good vibrations and love. The trouble is that it does not do this very well: the problem, he says, is that "it maintains a critical position about everything but itself"; it is always thwarted in one way or another (for example, by prevailing ideology). However there is, he says, "virtue in the state of the beautiful soul. Like an intense form of religion, beautiful soul syndrome shows us how far we would have to go to change things utterly". (Morton 2007, p. 122, emphasis is my own). So, ideally, (and why shy away from this word-this is a kind of cosmic Hegelianism and Morton reminds us he is a 'whollist') this ethical ambience would come to pervade the universe. It is a clear enough image: it is like you are out clubbing, all loved up and at one with the crowd and the universe, however when the music ends and the club closes you are tipped out into the consumerist city and its garbage-strewn streets, where there is a bidding war going on for the taxi you want to get you home. The beautiful ethically-ambient soul pops back into existence and re-individuates in the form of a rabid egotist. The Aufhebung - the continuance of the consumerist catastrophe-is all around you again. The beautiful soul for Morton as for Hegel thus represents a form of ethical failure - the failure is typical of religiosity, yet its secular equivalent is surely just as prevalent today. At the end of Ecology Without Nature, on the penultimate page, we find another strikingly definitive statement on the ethical dimension of the situation: "The only firm ethical option in the current catastrophe ... is admitting to the ecologically catastrophic in all its meaningless contingency, accepting responsibility groundlessly, whether or not we ourselves can be proved to be responsible". (Morton 2007, p. 204, emphasis is my own. $)^{4}$. In this formulation it is not clear whether the responsibility referred to is to be read as ethical responsibility or just as a 'general responsibility' for the material harm or damage done to the ecological whole. Furthermore, either way the use of "admitting" and "proving" is peculiar: what kind of a tribunal is Morton imagining here? Whatever it is, we remain stuck with the question of who or what might admit or confess to whom or to what-and to what exactly? Perhaps the very last paragraph of the book attempts to clear this up:

To emerge from the poisoned chrysalis of the beautiful soul, we admit that we have a choice. We choose and accept our own death, and the fact of mortality among species and eco-systems. This is the ultimate rationality: holding our mind open for the absolutely unknown that is to come. (Morton 2007, p. 205)

Does this mean each of us individually, as a species collectively, the hive mind as it were; or as something else we are not yet? And is this a rowing back toward a DerrideanLevinasian thinking of the 'to come' or the beyond as the unthinkable origin of ethical obligation? His answer would seem to be borne by this warning and injunction: "if we aestheticize this acceptance [namely, of the mortality, as such, of all co-existing living things] then this leads to fascism, the cult of death. Instead ecological criticism must politicize the aesthetic". (Morton 2007, p. 205) If by this he means that the ideal form of the "ethical ambience" he speaks of earlier in the book must be politicized, then highly attractive as this is, is it not also highly politically dangerous? It would be dangerous, as it too involves a reduction: the reduction that takes the form of the assertion of the non-difference 
or de-differentiation of the ethical and the political. It risks, at least, I suggest, a sort of Dionysian fascism (the frenzied 'annihilism' that breaks out in Euripides play The Bacchae, for example), a scenario in which the endpoint, or catastrophe becomes a self-fulfilling prophecy in which the "who or what is to come', "the forever coming, always yet to come", actually comes, and comes in the form of a supra-identification with a totality. This is arguably a kind of 'wake up call', although one that comes in the form of a fist in the face. In addition, the only thing still yet to come at that point is perhaps a diabolical dissolution of all things as an actuality. If you do not want to have to counter the aestheticization of the political with the politicization of the aesthetic, I am saying, then do not aestheticize the ethical in the first place within your aesthetico-ontology.

The supra-identification with totality is of course not at all what Morton wants, let us be clear; indeed, it is what he seeks to aver and forestall, namely, the frenzied fascism (it is not too strong a word) of generalized, insatiable 'consumerism'. However what I am questioning, nonetheless, is the idea that an aestheticized phenomenology of individuation (aka imagined individuation) can serve as the basis for this. (I am doing my best here to engage with him on the issue of how to escape the likely fate of anthropization-the control of the environment since the beginning of agriculture, and so forth, now become 'generalized consumerism', whilst expressing skepticism with regard to the aestheticization of the ethical. My own concern is that this reduces ethical obligation to a subjective 'feeling' in an imaginary 'me'. Let us read a few emblematic lines from The Ecological Thought:

The ecological thought imagines interconnectedness, which I call the mesh. Who or what is interconnected with what or with whom? The mesh of interconnected things is vast, perhaps immeasurably so. Each entity in the mesh looks strange. Nothing exists all by itself, and so nothing is fully "itself". [ . . . Our encounter with other beings becomes profound. They are strange, even intrinsically strange. Getting to know them makes them stranger. When we talk about life forms, we're talking about strange strangers. The ecological thought imagines a multitude of entangled strange strangers. (Morton 2010, p. 15)

Morton's ontology is expressed clearly enough here: it is an onticology of 'multitudinous co-existences', within which the intimate-uncanniness of the strangely-familiar is encountered everywhere in the connections between anything-whatever with any-otherthing-whatever.

The ' $\mathrm{I}$ ' thus sees itself in every thing, but as every thing is unique, all such encounters are uncanny 'disturbances' of the self-same-me-in so far as the self is a 'thing' too. This is not, indeed, the mimetic reflection that keeps the uncanny at bay-all mirroring is already uncanny: there is a strange uncanniness, for example, in seeing one's own face in any mirror-even the one in your bathroom, for example. (Shock horror-a doppelganger! Argh! My father, and so forth.) If the philosophy of anthropocentric modernity had come to see itself as the 'mirror of nature', today thinking is unsettled by the uncanniness of the post-natural, 'after nature'. This uncanniness arises with the discovery that attends it, namely, that I see myself reflected in the mirror of anything-whatever-in a fly's compound eye perhaps-and not just any fly but just this one fly, this one as much as any other one (thing), right here right now; the one staring at me and making me wonder whether or not I should swat it as the intermittent buzzing is interrupting my project of finishing this very sentence. (I hold off, I open the window-it departs; this is an onticological democracy after all. Good old me! I let all beings be.) The me/not-me, distinction is unstable, dynamic, freaky and uncanny and, more and more for Morton, just 'weird'. For sure this is not the overflowing of the Infinite within the finite of Levinas-for whom real-world responsibility for the other $\left(l^{\prime}\right.$ autre) is at once an orientation towards the Infinite Other beyond Being (L'Autrui). Morton's onticology, rather, presents a scene in which the 'who or what' is no longer to come, but is come amongst us, in a sense is us 'as well', in so far as everything is enmeshed, or, rather, 'everything' is an illusion, there is only a multiplicity of contingent enmeshments of things. There is no 'beyond' the mesh of enmeshed-beings: this is the 'flat ontology' axiomatic of object-oriented-ontology. No Sein, no Dasein, just seiendes and what you see is what you get. 
To Morton's credit, it must be said, in this image, what you do not see (the imperceptible, what is off the scale of human perceptibility) you get even more of all that- "it's vast" and "immeasurable" (it is the mathematical infinite —Cantorian set theory, the weirdness of infinity plus $n$ equals infinity.) The Heideggerian Seinsfrage, despite being an analytic of immanence is as much an illusion on this score as the Levinasian 'Infinite within the finite': there is only an ontic mesh of all things and the strange strangeness of what we perceive, and equally (that is, in no way differently) the strange strangeness, too, of the imperceptible whole in all its uncanny weirdness. The strangeness of anything to any other thing and every other thing; strange strangeness is, and everything is homogenously distributed.

As fascinating and provocative as Morton's texts at times are, and as clear as the implicit concern for the future of the environment is in his intellectual project as a whole, it is difficult, perhaps impossible, to discern with any precision in his work an ecological ethic as such. What he does provide is an ontological perspective that includes an injunction for a maximally expansive, all-encompassing "radical openness to everything" (Morton 2010, p. 15). To be enmeshed-with or entangled-with everything suggests a view of ethicality as built into the automaticity of being conceived as thingly co-existence. The trouble with this general ontology of the co-existentiality of 'everything'; this meshing all things, however, is that it leaves no space for alterity at all. It may be a post-anthropocentric ontology, moreover one which frees itself of 'correlationism', however it also represents the refusal of any notion of a reflexive species-responsibility as such. It portends rather, I suggest, a culture of super-individualism that today is still in the process of becoming complete: a democracy of things perhaps, but also a 'cancel culture' par excellence; a culture in which every individual thing is 'offended' (in the sense of repulsed by) every other thing and, logically therefore, antithetical to any notion whatever of 'collective responsibility'. Collective responsibility would be the absolute antithesis of such thingly identitarianism. This is an image of a crisis stricken 'world' or Earth that is in the process of devouring itself. Now, one may argue that this ought not to be viewed in wholly negative terms: Donna Haraway for example has argued that an alimentary 'becoming-compost' is the end of and the beginning of all life, and at the heart of all future possibilities of multispecies community. 'Compostism' is her name for the vitalist-materialist physics at work in world-making and world-remaking ${ }^{5}$. My criticism of this idea in both its Mortonian and its Harawayian forms is that it asserts and celebrates the passing, or the foreclosure of the possibility, of any putative, historically or geographically 'localised' group-responsibility that might be identified, or any group that might even identify itself qua being responsible for the suffering and deprivation that comes with the anthropocene and the climate crisis. For example, forms of group-responsibility that might be associated with a 'we' that can speak the words "we are to blame", as in, for example, "we the rich", "we in the North", "we moderns", over against the poor and the destitute, those in the Global South, racialised 'others' or indigenous peoples. ${ }^{6}$

Joanna Zylinska in her admirable book Minimal Ethics for the Anthropocene counts both Morton and Haraway amongst the crowd of posthumanist fellow thinkers who make original contributions to thinking the anthropocene from an ethical as well as a political perspective. She draws directly, substantively and uncritically on Morton, and the key chapter of 'Ethics' identifies and aligns her notion of 'minimal ethics' with Morton's thinking of 'radical openness to everything' (cited above). "The minimal ethics of the Anthropocene ... becomes, to cite Timothy Morton, a form of 'radical openness to everything'. (Zylinska 2014, p. 95). This 'ethical minimalism' for Zylinska refers to the maximally expansive distribution of the ethical across the entire ontological field of relations - the ethical openness of everything to everything else, as it were. Ethical obligation and responsibility take the form of a disturbing, ethical demand implicit to relations and to relatedness as such (一and this aspect of the ethical so understood that she identifies with Levinas' ethics), but it is 'minimal' in so far as it is located in the entangled relationships that exist between things. As far as humans are concerned, this is between themselves and myriad of thingly alterities they are entangled with, not all of whom (or which) are human, and being human is not 
a condition of being in an ethical relationship. Whilst conventional Levinasian scholars might have trouble recognizing Levinasian ethics in this appropriation of his notion of ethical demand, Zylinska thus proceeds to relieve Levinas of his anachronistic retention of a certain humanism (the 'humanism of the other $\mathrm{man}^{\prime 7}$ ) and presents an image of the ethical as credible admixture of the Levinasian account of the passivity of the ethical subject in conjunction with a de-anthropcentrised field of relations/enmeshments/entanglements of lived experience and multifarious ethical encounters. Whilst Zylinska's notion of minimal ethics, as articulated in this text, leaves space for the singularity of the capacity for humans to 'make a difference' in the world-and this principle of differentiation is considered the very nature of 'ethicality', ethics is no longer to be seen as an exclusively human matter in the universe. So whilst futural 'responsibility for the Earth' for the minimal ethicist Zylinska, must be thought beyond the human and beyond the hubris of the masterly modern humanism of the anthropocene, there is nonetheless scope in this ethical theory for at least some differentiated manifestation or other of 'the human', and thus for humans to take some form of 'species-responsibility' for its part and its place in the contemporary ecological crisis. Furthermore, whilst Zylinska seemingly unproblematically views Morton as a contributor/fellow traveler (at least at this point in time) - and a fellow post-deconstructivist, neo-Levinasian to boot-his own appropriation of elements of that tradition (and especially its coupling in his work with object-oriented-ontological thinking) is, in my view, deeply problematic.

As important as the likes of Heidegger, Derrida and Levinas are for Morton-and deconstruction is referred to at one point as "the secret best friend of eco-criticism" (Morton 2014, p. 296) - their appearances in his account are bizarrely, seemingly often premised on 'inversions' of their most explicit propositions. This includes those that may (or may not) be appropriable for thinking the ethical through the ecological: say, perhaps, with Heidegger in the discourse of Sorge/Fürsorge implicit to the thought of Being as the analytic of Dasein; or Derrida's thinking of the apocalyptic and the arrivant, or Levinas' account of the Infinite within the Finite as the manifestation of ethical responsibility. He consistently cuts off, in a way refuses, or turns away from whatever in their thinking calls for thinking beyond the phenomenal. So, for example, Heidegger's account of the ontological difference is considered profoundly insightful, however his privileging of the ontological over the ontic gets reversed. Derridean deconstruction, provides an invaluable account of how 'language never says what it means and never means what it says, and this is the condition for it's being able to say anything at all', however the 'end of the world' as a referent is precisely not 'apocalyptic' in the sense Derrida gives to this, discussed above, but rather the end of an illusion-namely the illusion that there ever was a world. Two of the longest quotations in Ecology Without Nature are afforded to Levinas and Heidegger. The page length Levinas quotation (Morton 2007, p. 60) is from Existence and Existents (Levinas 1978, p. 58), the section on the il $y a$, in which despite the fact that Levinas writes it almost as a polemic against Heidegger's account of the es gibt in Being and Time, Morton's minimal commentary at that point ignores this completely. He reads this text rather as evidence that they both make the same phenomenological discovery that the fundamental modality of life is aesthetic. He does not acknowledge that this account in Levinas is part of the phenomenological work Levinas does on the "upsurge of the existent" from the impersonal 'horror' of existence as indeterminate, pre-personal being (as Levinas puts this), and that this arc of coming into being of the substantive 'existent', the ' $\mathrm{I}$ ' or the 'me' for Levinas, is provoked by the ethical relation to the Other said to precede it. In other words, he does not read this in conjunction with the fuller exposition it receives in Levinas' later magnum opus, Totality and Infinity. Now, of course I am not suggesting that Morton, or anyone else, should not be selective in any way he chooses in the service of his own attempt to articulate and express a view of the fundamental character of the 'interconnectedness of all things', and so forth. However, the retro-fitting of cannibalized versions of the thought of these others in the service of an aestheticized account of the ethical they would not recognize and would refuse, must be noted. This is not so surprising given that Morton's reading of 
Heidegger is strongly influenced, one may even say mediated and derived from Graham Harman's reading of the philosopher. ${ }^{8}$ This is not the place to attempt a detailed critique of Morton's, in my view, weird marriage of deconstruction and object-oriented ontology, although it is worth noting here that Harman's reading of Levinas effectively provides the framework for it. Somewhat iconoclastically, Harman (2007) argues that the principal Levinasian contribution to philosophy is the discovery of the primacy of the aesthetic, and he attempts to co-opt Levinas in the service of his own account of how aesthetico-ontology warrants the title of 'first philosophy'. He does this despite the fact that Levinas himself dedicated his life's work to communicating the notion of ethics as first philosophy, and ipso facto, writing against the entire Western philosophical tradition. Morton still credits both Heidegger and Derrida, and one might also presume he would include Levinas in his list too, as "prophets of ecological thought" — which perhaps they are, however, as I hope is clear at this point, I am not so sure that is the case with respect to his own philosophy.

I hope what I said earlier about the potential risk that comes with the aestheticization of the ethical will suffice here as marker for concern vis-a-vis my own title question. My 'objection' to this, as we find it in Morton's thought, is that if you dissolve the ethical in the aesthetic and then critique the aestheticization of politics (as fascism) calling for its reversal (as the policiticization of the aesthetic), then you are pinning your hopes on a political ontology that arguably forsakes the ethical entirely. Maybe it is the case that ethics is part of the 'big illusion' we just have to learn to live without-and not least for its alltoo-humanness. If what one means by 'ethics' is a relationship implying the transcendence of a metaphysical ethical guarantor, then I entirely agree with that, however that is not what either Levinasian or Derridian discourses of 'infinite responsibility' articulate. This is Derrida from Remarks on Deconstruction and Pragmatism:

I would say for Levinas and myself, that if you give up on the infinitude of responsibility, there is no responsibility. It is because we act and live in infinitude that responsibility with regard to the other (autrui) is irreducible. If responsibility were not infinite, if every time I had to take an ethical or political decision with regard to the other (autrui) this were not infinite, then I would not be able to engage myself with respect to the infinite debt with regard to each singularity. (Derrida 1996, p. 86)

Nothing in the above proposes anything other than that ethical responsibility is livedout and lived-within this Earth/environment thing, in the everyday, here and now and indeed within sensate life, and in the name of (its) survival and what is to come. I would even suggest it is in the spirit of Morton's own ecological thought, even though I struggle to find it in the letter of it sometimes, in so far as we do indeed need to develop an ecoethico-politics that can deal with "vastness" and the imperceptibility of the planetary environment-biosphere. ${ }^{9}$ I do not question the striking contribution it is making to thinking ecologically in this age of environmental crisis, however, I am also inclined to think that ethical failure rather than just a failure of imagination needs to be addressed as such. It is not that these two things are not connected, they undoubtedly are: intellectual life, art, philosophy, science, creative expression and experimentation are all necessary to the process of thinking ecologically and, in Morton's phrase, 'being ecological'. 'Ethical obligation', however, as Derrida and Levinas have sought to show, is not a work of the human imagination alone, it is rather what 'comes' and provokes it, and places impossible, excessive demands upon it. To say humankind has a choice to act eco-politically or not, that is no doubt true; however, the notion of ethical responsibility we need today, perhaps more than ever before, calls for an attunement to the demand, not so much 'as we find it', but rather as 'it' — whatever it is, this environment thing - finds us; or rather 'founds us', for the first time, as it were, as irreducibly exceptional, irreducibly human. In the end phase of the anthropocene, we are for the first time, and the last perhaps, 'maximally human', although only, ONLY, ONLY, I stress, in our absolute responsibility for 'the mess'. (The slightest of changes in pressure between the tongue, teeth and breath just then, and you would have heard this last phrase-if I were speaking it to you face-to-face-as 'responsibility for the mesh'!) 


\section{Postscript}

Finally, after the end, a sort of footnote to a footnote: I promised earlier to return at the end to that footnote in Ecology Without Nature appended to these lines: "The only firm ethical option in the current catastrophe ... is admitting to the ecologically catastrophic in all its meaningless contingency, accepting responsibility groundlessly, whether or not we ourselves can be proved to be responsible". (Morton 2007, p. 204) I had first wondered if it signaled, 'derivation', 'agreement' or perhaps the 'paraphrasing' of Žižek. I realize now it is none of these. It is, rather, left hanging there as a sort of clue, left by the author, hidden in plain sight. Morton is, I now realize, riffing along with Žižek. In those pages of Looking Awry that Morton encourages us to read, Žižek is discussing detective stories and specifically, at that point, the role of the clue in detective fiction:

Starting from clues, the detective unmasks the imaginary unity of the scene of the crime as it was staged by the assassin. The detective grasps the scene as a bricolage of heterogeneous elements, in which the connection between the murderer's mise-en-scène and the "real events" corresponds exactly... [to] the immediate figuration of the rebus and its solution.

(Žižek 1992, p. 36.)

In view of this, it now also occurs to me that I might just as well have titled this article 'A footnote to a footnote in Morton's Ecology Without Nature'. My title question 'What on earth is ethical responsibility?' should perhaps be heard less in an interrogative tone and in one more akin to puzzlement and calling for attunement to this question as a rebus. The answer to the question of ethical responsibility for 'the Earth' should perhaps be approached foursquarely on the basis of the clues to be found at the 'scene of the crime', as it were. Furthermore, through this lens of 'the clue in the service of the detection', the apocalyptic discovery of the ethical responsibility for 'the ecological crime' is perhaps, in the end, that it is 'all mine'. I/we, whoever or whatever we are, and are to become, in the post-anthropocene, catch ourselves red-handed; our fingerprints are all over it.

Funding: This research received no external funding.

Conflicts of Interest: The author declares no conflict of interest.

\section{Notes}

See Derrida (1994) the 'Exordium' section and Boothroyd (2013) pp. 189-97.

For an interesting discussion of Levinas' remarks on Macbeth see Doenges (2010).

For example see Ursula K. Heise's (2014) pithy book review of Morton's Hyperobjects (2013): in a one-thousand words hatchet job she characterizes the book as being full of 'so many self-cancelling claims about hyperobjects that coherent argument vanishes like the octopi that disappear in several chapters in their clouds of ink'. My reading of Morton here focuses centrally on two of Morton's earlier works.

4 There's actually a numbered footnote reference to three pages in Žižek's Looking Awry (Žižek 1992, pp. 35-39) at that point (Morton 2007, p. 237, fn. 189) without explanation. So it is unclear whether he is signaling derivation, paraphrase or agreement with Žižek, I shall return to this later, at the very end of this article.

5 See Haraway (2016).

6 See Yussof (2018) on the multiple histories and genealogies of 'humaness' and their refigurings in contemporary discourses of the anthropocene.

See Levinas (2006) and for a discussion of this phrase, Llewelyn (1995, p. 132).

Above all Harman's major work Tool-being: Heidegger and the Metaphysics of Objects (Harman 2002)

For a discussion of the dialectic of perceptibility/imperceptibility of planetary shifts see Rob Nixon's Slow Violence (Nixon 2013).

\section{References}

Backman, Jussi. 2017. The End of the World after the End of Finitude: On a Recently Prominent Speculative Tone in Philosophy. In The End of the World: Contemporary Philosophy and Art. Edited by Marcia Sa Cavalcante Schuback and Sussana Lindberg. London: Rowman and Littlefield, pp. 105-23.

Boothroyd, Dave. 2013. Ethical Subjects in Contemporary Culture. Edinburgh: Edinburgh University Press. 
Derrida, Jacques. 1979. LIVING ON. Border lines. In Deconstruction and Criticism. Translated by James Hulbert. New York: Continuum, pp. 75-176.

Derrida, Jacques. 1984. Of an Apocalyptic Tone Recently Adopted in Philosophy. Oxford Literary Review 6: 3-37. [CrossRef]

Derrida, Jacques. 1993. Aporias: Dying-Awaiting (One Another At) the 'Limits of Truth'. Translated by Thomas Dutoit. Stanford: Stanford University Press.

Derrida, Jacques. 1994. Specters of Marx. Translated by Peggy Kamuf. London: Routledge.

Derrida, Jacques. 1995. The Gift of Death. Translated by David Wills. Chicago: Chicago University Press.

Derrida, Jacques. 1996. Remarks on Deconstruction and Pragmatism. In Deconstruction and Pragmatism. Edited by Chantal Moufffe. London: Routledge, pp. 77-88.

Derrida, Jacques. 2001. The Work of Mourning. Edited by Pascale-Anne Brault and Michael Naas. Chicago: Chicago University Press.

Derrida, Jacques. 2007. Learning to Live Finally: The Last Interview. Translated by Pascale-Anne Brault, and Michael Naas. Hoboken: Mellville House Publishing.

Derrida, Jacques. 2020. LifeDeath. Edited by Pascale-Anne Brault and Michael Naas. Chicago: Chicago University Press.

Doenges, Nicholas. 2010. A Levinasian Meditation on Shakespeare's Macbeth. Levinas Studies 5: 167-88. Available online: https: / / www.jstor.org/stable/10.2307/26942895 (accessed on 25 September 2021). [CrossRef]

Haraway, Donna. 2016. Staying with the Trouble. Durham and London: Duke University Press.

Harman, Graham. 2002. Tool-Being: Heidegger and the Metaphysics of Objects. Chicago: Open Court.

Harman, Graham. 2007. Aesthetics as First Philosophy: Levinas and the Non-Human. Naked Punch 9: 21-30.

Heise, Ursula K. 2014. 'Ursula K. Heise Reviews Timothy Morton's Hyperobjects'. Critical Inquiry. Available online: https:// criticalinquiry.uchicago.edu/ursula_k._heise_reviews_timothy_morton (accessed on 6 January 2022).

Kant, Immanuel. 2002. On a Recently Prominent Tone of Superiority in Philosophy. Translated by Peter Heath. In Theoretical Philosophy after 1781. Edited by Henry Allison and Peter Heath. Cambridge: Cambridge University Press, pp. 429-45.

Levinas, Emmanuel. 1978. Existence and Existents. Translated by Alphonso Lingis. The Hague: Martinus-Nijhoff.

Levinas, Emmanuel. 2000. God, Death and Time. Translated by Bettina Bergo. Stanford: Standford University Press.

Levinas, Emmanuel. 2006. The Humanism of the Other. Translated by N. Poller. Chicago: University of Illinois Press.

Llewelyn, J. 1995. Emmanuel Levinas: The Genealogy of Ethics. London: Routledge.

Morton, Timothy. 2007. Ecology without Nature. Cambridge: Harvard University Press.

Morton, Timothy. 2010. The Ecological Thought. Cambridge: Harvard University Press.

Morton, Timothy. 2014. Deconstruction and/as Ecology. In The Oxford Handbook of Ecocriticism. Edited by Greg Garrard. Oxford: Oxford University, pp. 291-304.

Nixon, Rob. 2013. Slow Violence and the Environmentalism of the Poor. Cambridge: Harvard University Press.

Stiegler, Bernard. 2018. The Neganthropocene. Edited and Translated by Daniel Ross. London: Open Humanities Press.

Yussof, Kathryn. 2018. A Billion Black Anthropocenes or None. Minneapolis: University of Minnesota Press.

Žižek, Slavoj. 1992. Looking Awry: An Introduction to Jacques Lacan through Popular Culture. Cambridge: MIT Press.

Zylinska, Joanna. 2014. Minimal Ethics for the Anthropocene. London: Open Humanites Press. 